\title{
Revolución, derechos humanos y exilio: Montoneros y la Comisión Argentina de Derechos Humanos en los orígenes de la denuncia de la dictadura argentina (1976-1980)
}

\author{
Revolution, human rights and exile: Montoneros and the CADHU in the \\ beginning of the denunciation of the Argentine dictatorship (1976-1980)
}

\author{
Hernán Eduardo Confino \\ hconfino@gmail.com \\ Instituto del Desarrollo Humano/Universidad \\ Nacional de General Sarmiento - CONICET - \\ Escuela Interdisciplinaria de Altos Estudios Sociales/ \\ Universidad Nacional de San Martín, Argentina \\ Rodrigo González Tizón \\ rgtizón@gmail.com \\ Archivo Nacional de la Memoria - Escuela \\ Interdisciplinaria de Altos Estudios Sociales/ \\ Universidad Nacional de San Martín, Argentina
}

Recepción: 07 Agosto 2020

Aprobación: 01 Diciembre 2020

Publicación: 01 Marzo 2022

Cita sugerida: Confino, H. E. y González Tizón, R. (2022). La Huelga de Inquilinos de 1907 en Rosario: Una aproximación. Sociohistórica, 49, e156. https://doi.org/10.24215/18521606e156
Resumen: Este artículo propone un cruce, a través del exilio, entre dos campos que hasta la actualidad no han dialogado en profundidad: el de las investigaciones sobre las organizaciones armadas y el de los estudios sobre el movimiento de denuncia de las violaciones a los derechos humanos de la última dictadura argentina. Por eso, profundiza en los vínculos que se establecieron entre la organización armada Montoneros y la Comisión Argentina de Derechos Humanos (CADHU) desde el comienzo de su "exilio orgánico", entre fines de 1976 y principios de 1977, hasta la realización del "testimonio de París” y la última disidencia montonera, entre fines de 1979 y principios de 1980. A través de un mosaico de fuentes que incluye documentos partidarios, entrevistas a los protagonistas e informes desclasificados de la inteligencia militar, el trabajo aborda el rol desempeñado por las organizaciones armadas en la constitución de las redes que motorizaron inicialmente la denuncia transnacional de las violaciones a los derechos humanos cometidas por la dictadura en la Argentina.

Palabras clave: Exilio, CADHU, Montoneros, Derechos Humanos, Revolución.

\begin{abstract}
Throw an exploration of Argentina's last dictatorship exile, this article proposes an intersection between two fields that haven't been articulated in depth before: guerrilla groups and human rights movement studies. With this aim, the work analyzes the political ties between Montoneros guerrilla and the Argentine Human Rights Committee (in Spanish, CADHU) since their organized exile, towards the end of 1976 and the beginning of 1977 , until the public presentation of the "Paris testimony" and Montoneros' last breakdown, towards the end of 1979 and the beginning of 1980. Putting different kind of documents together -including political publications, interviews and military intelligence unclassified documents-, this article explores the participation of guerrilla groups in early networks of human rights transnational denunciation.
\end{abstract}

Keywords: Exile, CADHU, Montoneros, Human Rights, Revolution. 


\section{INTRODUCCIÓN}

El 12 de octubre de 1979, tres militantes de Montoneros que habían sido recientemente liberadas del centro clandestino de detención (CCD) que funcionaba en la Escuela de Mecánica de la Armada (ESMA) en Buenos Aires - Ana María Martí, Sara Solarz y Alicia Milia- se presentaron ante la Asamblea Nacional, en París, para ofrecer el testimonio del cautiverio que habían padecido. El evento incluyó una conferencia de prensa y estuvo encabezado por Bernard Stasi, presidente de la Comisión Interparlamentaria de Derechos Humanos. El llamado "testimonio de París" fue patrocinado y publicado por la Comisión Argentina de Derechos Humanos (CADHU), organismo que se había formado en la Argentina entre fines de 1975 y principios de 1976 en torno a un grupo de abogados defensores de presos políticos. Contó, además, con la participación de Montoneros en su organización, a través de gestiones previas con actores políticos franceses (Franco, 2008; Jensen, 2010).

El evento en París se desarrolló en una coyuntura en que las violaciones a los derechos humanos de la dictadura argentina habían adquirido una potente visibilidad internacional. Durante 1977, distintos funcionarios del régimen militar habían declarado a la prensa local el triunfo en la "guerra contra la subversión”; además, elaboraron una campaña publicitaria para mejorar la imagen internacional del gobierno en vistas del mundial de fútbol en el país en junio de 1978 (Canelo, 2016). Esa imagen había sido mellada por las constantes denuncias que habían motorizado distintas organizaciones de exiliados en relación con las redes transnacionales de derechos humanos, cuyas acciones fueron interpretadas por el gobierno de facto como parte de una "campaña antiargentina" para dañar la reputación del país (Franco, 2008). Un mes antes del testimonio colectivo en la Asamblea Nacional francesa, en septiembre de 1979, en el marco de este aumento de la presión internacional sobre la dictadura, se había producido la visita a la Argentina de la Comisión Interamericana de Derechos Humanos (CIDH) de la Organización de los Estados Americanos (Jensen, 2010).

El "testimonio de París" inauguró una etapa en la que la figura del testigo se consagró, no sin conflictos, como engranaje central de la denuncia (González Tizón, 2021). El testimonio de las tres militantes montoneras se dio en un momento particular y trascendental de la trayectoria de la denuncia antidictatorial en el exterior del país. Al mismo tiempo, fue resultado de una serie de dinámicas históricas previas entre las que se cuentan tanto la participación exitosa de los organismos de exiliados en las redes humanitarias transnacionales como la actividad de denuncia emprendida por parte de las organizaciones armadas (Confino, 2020). El estudio de esas dinámicas, con sus intersecciones y bifurcaciones, es el objetivo de este texto.

En el presente artículo interrogaremos las condiciones históricas de posibilidad del "testimonio de París”. Esto implica, en un plano más general, reconstruir la trayectoria previa de los diferentes actores que organizaron y participaron del acontecimiento. Por esta razón, el recorrido que propone este trabajo se inicia en el plano local y aborda el desplazamiento hacia el exilio y la conformación de una oposición transnacional a la dictadura, poniendo de relieve los vínculos tempranos entre el activismo local y el que se desarrolló en el exterior. Para ello, prestaremos atención a las relaciones, de articulación y también de conflicto, que se gestaron al interior de los organismos de exiliados entre la política revolucionaria y su par humanitaria, y tomaremos, por caso, los itinerarios de dos organizaciones vinculadas pero independientes: la CADHU y Montoneros, ambas partícipes del "testimonio de París".

Una serie de preguntas guía nuestra indagación: ¿cómo se conformó el entramado político que dio origen al testimonio de las tres sobrevivientes de la ESMA? ¿Qué actores se involucraron en su realización? ¿Cómo fueron los vínculos entre Montoneros y la CADHU y cuál fue la participación de ambas organizaciones en la red transnacional de denuncia que constituyó el movimiento de derechos humanos?

En los últimos años, numerosos trabajos del campo de los exilios políticos de la década de 1970 se han interesado por los itinerarios de las formaciones partidarias argentinas en el destierro (Osuna, 2014; 
Carnovale, 2014; Casola, 2014; Calderoni, 2017; Mangiantini, 2017; Confino, 2018). El exilio, de este modo, dejó de ser representado meramente como un efecto de la represión estatal y comenzó a ser considerado, también, "como una resolución militante o una redefinición de dimensiones colectivas" (Jensen y Lastra, 2014, p. 11). Este artículo refrenda esa caracterización y se vale del corpus clásico de trabajos sobre el tema, los cuales delimitaron sus objetos a partir de las sociabilidades que se desplegaron en los principales países de acogida, para pensar y reconstruir las redes transnacionales que se estructuraron entre la Argentina, y el exterior y que se desplegaron fundamentalmente en México, Estados Unidos y diversas capitales europeas durante la segunda mitad de la década de 1970 (Jensen, 2007; Franco, 2008; Yankelevich, 2010).

Solo recientemente, y apoyada en las reconstrucciones -sólidas aunque fragmentarias- de los trabajos pioneros sobre el exilio, la historiografía sobre Montoneros ha comenzado a abordar la experiencia de la organización en el exterior (Confino, 2018; Robledo, 2018). Como parte del crecimiento del campo, la CADHU también ha sido materia de indagación en algunos trabajos previos. Estas investigaciones destacaron su origen en torno a un grupo de abogados defensores de presos políticos (Rot, 2015), su particular configuración militante y su adopción del lenguaje de los derechos humanos (Copello, 2019), sus concepciones sobre la relación entre dictadura y sociedad civil (Jensen, 2014), su producción de saberes tempranos sobre la dictadura a partir de la publicación de testimonios de sobrevivientes de CCD (González Tizón, 2016 y 2021), y sus vínculos políticos con Montoneros (Confino, 2020).

Este trabajo propone tejer un cruce, a través del exilio, entre dos campos que hasta la actualidad no han dialogado en profundidad: el de las investigaciones sobre las organizaciones armadas y el de los estudios sobre el movimiento de derechos humanos. Ninguno de estos núcleos temáticos, por otra parte, se pensó en diálogo con las producciones sobre el último exilio político argentino. Por eso, en este artículo profundizaremos en los vínculos que se establecieron entre Montoneros y la CADHU desde el comienzo de su "exilio orgánico", entre fines de 1976 y principios de 1977, hasta la realización del "testimonio de París" y la última disidencia montonera, entre fines de 1979 y principios de 1980. La consideración de estos años y la escala transnacional adoptada permiten aproximarse a las relaciones que se dieron en el exterior entre praxis revolucionaria y activismo humanitario, y aportar a un tema escasamente tratado por la historiografía: el rol desempeñado por las organizaciones armadas en la constitución temprana de las agrupaciones de derechos humanos (Alonso, 2017).

La reconstrucción del derrotero de la CADHU y Montoneros plantea algunas dificultades debido al contexto represivo en el que desenvolvieron su práctica política, a la clandestinidad de la militancia y a la dispersión del exilio. Para saldar estas cuestiones, se utilizó un corpus de fuentes heterogéneas, que incluye documentación partidaria, informes de organismos de inteligencia y entrevistas con los protagonistas, además de bibliografía especializada.

El trabajo inicia con un apartado donde se exploran los vínculos tempranos entre la CADHU y Montoneros en la Argentina en el contexto de las primeras manifestaciones del terrorismo de Estado, y que se extiende hasta el "exilio orgánico" de ambas organizaciones, ocurrido entre fines de 1976 y mediados de 1977. Una segunda sección aborda las iniciativas de denuncia de la CADHU y Montoneros en el terreno del exilio con especial hincapié en las articulaciones y tensiones que se produjeron entre esas acciones, expresadas en clave de derechos humanos, y las que tenían como norte la revolución. Por último, el tercer apartado reconstruye las circunstancias de producción del “testimonio de París", interrogando el rol de la CADHU y Montoneros en la trama de vínculos y negociaciones que hicieron posible la conferencia de octubre de 1979.

\section{La CADHU y Montoneros frente aL terrorismo de Estado}

El escenario político planteado en la Argentina desde fines de 1974 y, especialmente, durante 1975, se caracterizó por una aguda conflictividad interna, un crecimiento de la actividad de las organizaciones político-militares y una represión estatal y paraestatal en ascenso (Servetto, 2010; Franco, 2012). En 
septiembre de 1974, Montoneros había optado por retornar a la clandestinidad abandonada desde el triunfo de Héctor Cámpora en las elecciones presidenciales del año anterior, hecho que profundizó su enfrentamiento con los sectores “ortodoxos" del peronismo (Gillespie, 1998). La otra gran expresión armada del país, el Partido Revolucionario de los Trabajadores-Ejército Revolucionario del Pueblo (PRT-ERP), se había abocado a planificar y ejecutar asaltos a las principales guarniciones del país para abastecerse de armamento, y al desarrollo de un "foco" guerrillero rural en la región del monte tucumano (Pozzi, 2004; Carnovale, 2011) $)^{2}$. En paralelo, las fuerzas parapoliciales - entre las que destacaba la "Triple A"- habían intensificado su campaña de secuestros, atentados, desapariciones y asesinatos en la vía pública (Besoky, 2016). El punto culminante de este proceso de agudización del conflicto político llegó en 1975, con la sanción de los decretos presidenciales que otorgaban a las Fuerzas Armadas la dirección de las acciones contra las organizaciones político-militares en nombre de la "seguridad interna" (Franco, 2012; Garaño, 2015; Pontoriero, 2016).

En este contexto se produjeron las primeras salidas del país de militantes montoneros, quienes buscaban resguardar su vida ante la creciente represión estatal y paraestatal. Durante la segunda mitad de 1974 y a lo largo de todo 1975, varios miembros de la organización abandonaron de manera inorgánica la Argentina con destino a México. Allí surgieron, con Rodolfo Puiggrós como referente principal y elemento aglutinador, las primeras estructuras de denuncia y solidaridad conformadas por exiliados (Acha, 2006; Yankelevich, 2010). El agrupamiento inicial contaba con una composición heterogénea: además de Puiggrós, estaban Noé Jitrik, Esteban Righi, Ricardo Obregón Cano y César Calcagno, entre otros. ${ }^{3}$ En ese momento inicial, el foco de la atención estaba puesto en los exiliados que llegaban cada vez en mayor cantidad. "Comenzamos a desarrollar tareas de solidaridad”, recuerda Calcagno, quien se desempeñaba como abogado de presos políticos vinculado a Montoneros. Detenido durante el gobierno de María Estela Martínez de Perón, había llegado a tierras mexicanas haciendo uso del derecho constitucional de "opción" en febrero de 1975, y rápidamente se había puesto en contacto con las redes desarrolladas en torno a Puiggrós.

En paralelo a las labores de solidaridad con los recién llegados comenzaron también a desarrollarse otras que tenían como eje la denuncia de la represión en la Argentina. ${ }^{4}$ Las coincidencias respecto a la necesidad de estas actividades no impidieron, sin embargo, el surgimiento de tensiones al interior de ese primer nucleamiento de exiliados argentinos, las cuales pronto devinieron en ruptura. Los motivos de la disputa fueron algunas diferencias de concepción política y, fundamentalmente, los intentos de Montoneros por controlar el flamante espacio. De la escisión resultaron dos organizaciones: la Comisión Argentina de Solidaridad (CAS), encabezada por Jitrik y Righi, y el Comité de Solidaridad con el Pueblo Argentino (COSPA), dirigido por Obregón Cano y Puiggrós, y constituido formalmente en febrero de 1976. Este último, si bien estaba compuesto por distintas expresiones políticas, se mantendría cercano a la línea montonera (Acha, 2006; Yankelevich, 2010).

Mientras se producían estos primeros exilios, fronteras adentro de la Argentina comenzaron a gestarse diversos agrupamientos con la intención de denunciar la creciente represión estatal y paraestatal en el país. Los primeros de ellos, de tipo partidario, e incluso algunos vinculados a las organizaciones de la Nueva Izquierda, surgieron en la etapa previa, durante las dictaduras de la "Revolución Argentina", y tuvieron como actividad primordial la defensa de los presos políticos. Su creación fue consecuencia del salto en la persecución que siguió al "Cordobazo" y, todavía más, luego de la "Masacre de Trelew" de agosto de 1972 (Chama, 2007; Eidelman, 2009; Solís, 2014). En este contexto surgieron, entre otros, la Comisión Peronista de Ayuda a los Presos Políticos, la Comisión de Familiares de Presos Políticos, Estudiantiles y Gremiales (COFAPPEG), la Organización de Solidaridad con los Presos Políticos, Estudiantiles y Gremiales (OSPPEG) y la Comisión Peronista de Ayuda a los Presos Políticos (COPPAP) $)^{5}$. A estos organismos se sumaron, ya durante el tercer gobierno peronista, otros de impronta específicamente humanitaria, como el Servicio de Paz y Justicia (SERPAJ) y la Asamblea Permanente por los Derechos Humanos (APDH). 
La creación de la CADHU, cuyos orígenes se remontan a los meses finales de 1975, se inscribió en ese proceso más amplio. El proyecto surgió de un grupo de profesionales del derecho ligados a la Asociación Gremial de Abogados con experiencia en la defensa de presos políticos durante las dictaduras previas (Rot, 2015). De las reuniones preliminares a la fundación del organismo, formalizado en torno a abril de 1976, participaron representantes de diversas fuerzas políticas y algunos abogados que se desempeñaban en el ámbito sindical. ${ }^{6}$ El núcleo de la CADHU se estructuró alrededor del Partido Revolucionario de los Obreros Argentinos (PROA), fuerza integrada, entre otros, por los hermanos Eduardo Luis, Marcelo y Carlos María Duhalde, Haroldo Logiurato, Carlos González Gartland e Ignacio Ikonicoff (Rot, 2015). A ellos se sumaron, procedentes de Córdoba, los abogados Lucio Garzón Maceda y Gustavo Roca. Un tercer contingente de miembros procedía de Montoneros y el PRT- ERP, que acercaron nombres como los de Rodolfo Mattarollo, Manuel Gaggero, Martín Federico, Lidia Massaferro, Juan Carlos Caprioli o Pablo Ramos (Memoria Abierta, 2003b; Carnovale, 2014; Rot, 2015).

Durante el primer año de dictadura, la actividad de denuncia y solidaridad se caracterizó por la confluencia de esfuerzos entre la CADHU y las estructuras montoneras que funcionaban dentro y fuera de la Argentina, donde el organismo de derechos humanos también se había propuesto dar a conocer los crímenes de la represión. Los acuerdos establecidos entre el PROA y las organizaciones político-militares resultaron fundamentales para el cumplimiento de esta tarea, que se llevó adelante en el país principalmente a través de Ignacio Ikonicoff, quien se encargaba de centralizar los datos aportados por las colaboradoras y los colaboradores vinculados a Montoneros y el PRT-ERP (Rot, 2015). Este circuito permitió a la CADHU acceder de manera veloz y temprana a información detallada sobre la represión dictatorial, y, luego, difundirla a través de sus boletines de denuncia. El esquema permitiría, incluso, sacar información del país cuando el organismo estableciera delegaciones en distintos puntos del exilio.

La denuncia en el extranjero se planteó para la CADHU como una prioridad desde el inicio de su actividad. Ya en sus Estatutos, aprobados en la Asamblea Constitutiva, que tuvo lugar en Buenos Aires el 16 julio de 1976, establecía una representación exterior con ese objetivo. ${ }^{7}$ Esta proyección del organismo hacia el plano internacional respondía no solo a las convicciones de sus integrantes, sino también a las urgencias y peligros que imponía el contexto dictatorial: la reconocida trayectoria como abogados de varios de los miembros de la CADHU los volvía blancos probables de la represión. Las alarmas se encendieron definitivamente con el secuestro de Mario Hernández y Roberto Sinigaglia, ocurrido el 11 de mayo de 1976, en la previa a una reunión de discusión. El evento marcó un punto de inflexión en la trayectoria del organismo, el que, luego de algunas deliberaciones, definió la salida del país de varios de sus militantes más prominentes.

El exilio de los integrantes de la CADHU replicó la fisonomía general del destierro argentino: México, España y Francia fueron los puntos elegidos como destino, con la idea de organizar allí delegaciones del organismo. A estos países se sumaría con posterioridad Estados Unidos, donde se desarrollaría una experiencia con una dinámica distinta, y, hasta cierto punto, autónoma de las otras sedes (Santucho, 2004; Robledo, 2021). En México, donde se estableció González Gartland, rápidamente se entablaron contactos con la comunidad de exiliados argentinos. Consolidada ya la diferencia de líneas entre el CAS y el COSPA, González Gartland optó por la segunda; se incorporó a la secretaría de relaciones internacionales del organismo, aunque en un lugar con "independencia política", sin abandonar su pertenencia orgánica a la CADHU (Memoria Abierta, 2003a). En esta decisión pareciera haber jugado un rol central tanto la estructura desarrollada por el COSPA en México, que habilitaba una incidencia en el espacio público local mayor que la que podía ofrecer el CAS, como la mayor afinidad política con sus integrantes. ${ }^{8}$ Según González Gartland, esas redes pesaron incluso más que las potenciales diferencias políticas con Montoneros, "con los cuales disentía enormemente en muchas cosas, pero en esa época no en la denuncia" (Memoria Abierta 2003a).

Europa occidental fue el otro destino al que arribaron tempranamente los integrantes de la CADHU. Algunos de ellos habían llegado allí un tiempo antes, como era el caso de los que tenían vínculos con el PRT- 
ERP. Mattarollo, quien había salido con destino a Francia en 1975, se estableció en París. La elección tuvo que ver con las posibilidades que esta ciudad ofrecía para llevar adelante la denuncia, dada su cercanía con diversos foros humanitarios internacionales (Memoria Abierta, 2003c). La salida de Gaggero de la Argentina, por su parte, estuvo relacionada con la crisis aguda que atravesaba el PRT-ERP luego del asesinato y secuestro de sus máximos dirigentes en julio de 1976 (Carnovale, 2014). En septiembre de ese año, un enviado del partido lo instó a salir del país para asistir a una reunión del Comité Ejecutivo que se realizaría en la ciudad de Roma. Después de eso, debía establecerse en el exilio: "La idea era 'se van a Francia porque ahí está la CADHU', y mi tarea iba a ser la de estar en la CADHU” (Memoria Abierta, 2003b). ${ }^{9}$ No obstante, las dificultades idiomáticas finalmente lo llevaron a instalarse junto a su pareja e hijos en Madrid. A esa ciudad llegó para emplazar una sede del organismo quien para entonces era ya su máximo referente: Eduardo Luis Duhalde. Con el tiempo, CADHU España se convertiría en la delegación principal, lo que agrandaría aún más la figura de su fundador.

En paralelo a este proceso se produjo un acontecimiento de trascendental importancia para el devenir de Montoneros: luego de la reunión del Consejo Nacional de septiembre de 1976, la organización optó por trasladar progresivamente sus estructuras partidarias al extranjero (Baschetti, 2001). El secuestro y desaparición de numerosos militantes a manos de las fuerzas represivas habían obligado a repensar la estrategia en la lucha contra la dictadura, hasta entonces centrada en la resistencia dentro de la Argentina. ${ }^{10} \mathrm{La}$ decisión de Montoneros de dar comienzo al "exilio orgánico", que le permitió a su dirigencia esquivar la suerte corrida por la del PRT-ERP, tendría consecuencias directas en las redes denuncialistas tejidas previamente por los militantes de la organización en el extranjero, que, como ya mencionamos, incluían a la CADHU. ${ }^{11}$ Nuevamente México se convirtió en el escenario de las principales tensiones: el establecimiento de la base de operaciones de la Conducción montonera en ese país a fines de 1976 reactualizó las disputas por el control de la línea política en el exilio (Yankelevich, 2010).

Las dificultades crecientes para desarrollar la militancia dentro de la Argentina tuvieron como correlato una intensificación de la actividad en el exilio. Del lado de la CADHU, la publicación de los boletines internacionales - posibles gracias al trabajo de los colaboradores en el país- ${ }^{12}$ se vio acompañada por las presentaciones ante distintos foros internacionales. Un primer mojón en este terreno fue la denuncia de los crímenes dictatoriales que hizo Mattarollo ante la Subcomisión de Derechos Humanos de la ONU en agosto de 1976. ${ }^{13}$ A este evento le siguió la declaración de Lucio Garzón Maceda y Gustavo Roca, exiliados en Francia y España respectivamente, ante el subcomité de Organizaciones Internacionales de la Sala de Representantes de Estados Unidos los días 28 y 29 de septiembre de 1976. ${ }^{14}$ El encargado de las gestiones para la presentación de los miembros de la CADHU fue el "oficial montonero" Juan Gelman, entonces establecido en Roma junto a su pareja, Lidia Masaferro (ANM, 2020). La participación de Montoneros en el plano de la denuncia internacional, inaugurada por el COSPA mexicano y desarrollada a través de iniciativas puntuales de los militantes en el exilio, alcanzaba estatus de línea partidaria en la nueva coyuntura: el número de febrero de 1977 de Evita Montonera, canal de difusión oficial de la Conducción, se extendía sobre las acciones de la organización en el ámbito del exilio. Entre otras iniciativas, incluía dentro de su plataforma a la denuncia humanitaria, que se constituía nuevamente como el ámbito de encuentro político con la CADHU (EM, 1977a).

El período que se extendió entre los meses finales de 1976 y mediados de 1977 marcó el progresivo pero irrevocable traslado de la actividad de la CADHU y Montoneros al extranjero. Para la primera se trató de una interrupción total de la acción política en la Argentina, producto de los duros golpes que le propinó al organismo la represión dictatorial. El 11 y 12 de junio de 1977, en el marco de un plenario del PROA, fueron asesinados y desaparecidos en la localidad bonaerense de Marcos Paz los principales dirigentes partidarios que todavía estaban en el país. A partir de ese hecho, la Delegación Internacional de la CADHU, constituida a fines de 1976, pasó a funcionar de hecho como su Consejo Directivo. En el caso de Montoneros, 
la actividad en la Argentina no se detuvo por completo, pero disminuyó su intensidad considerablemente. Para comienzos de 1977, las principales estructuras de la organización en el país habían sido desarticuladas por la represión, solo quedaron en pie solo algunos núcleos aislados (Gillespie, 1998). En este contexto, la constitución del Movimiento Peronista Montonero (MPM) en Roma en abril de 1977 no parecía sino la aceptación de un hecho consumado: la imposibilidad de la organización de accionar contra la Junta Militar desde adentro de la Argentina.

\section{UNA OPOSICIÓN ARTICULADA: MONTONEROS Y LA CADHU EN EL EXILIO}

En los primeros meses de 1977, las denuncias que se acumulaban en el extranjero daban la pauta, además de la profundidad de la represión, de la conformación de una oposición efectiva a la dictadura, que buscaba llamar la atención de la comunidad internacional sobre los crímenes de la Junta Militar. Para ello, y tal como lo planteamos en el apartado previo, las organizaciones argentinas en el exterior habían intentado, con éxito variable, inscribir sus iniciativas políticas en la narrativa internacional contraria a la violación de los derechos humanos y articular con distintos y variados actores del circuito internacional de denuncias (Franco, 2008; Jensen, 2010, 2014).

El fortalecimiento de las actividades exiliares se adivina, por ejemplo, detrás de la publicación de las dos primeras investigaciones exhaustivas sobre las violaciones a los derechos humanos en el país, a cargo de la CADHU y de Amnistía Internacional. Argentina: proceso al genocidio, producido por la primera, contó con una amplia circulación internacional (Jensen, 2014; González Tizón, 2021). Publicada en marzo de 1977 a instancias del cineasta vasco Elías Querejeta, la investigación redactada por Eduardo Duhalde y Gustavo Roca, entre otros, reunía una decena de relatos del cautiverio clandestino -junto a otros tantos relativos a la detención en la cárceles legales del régimen- pero proponía, además, una interpretación política del terrorismo de Estado dictatorial. ${ }^{15} \mathrm{El}$ informe respaldaba una visión socioeconómica de la represión: era la persecución instrumentada por los representantes del capitalismo financiero mundial la que explicaba, para la CADHU, la persecución contra la clase obrera, identificada como el blanco predilecto del terrorismo de Estado. ${ }^{16}$ Esta interpretación económica y clasista de la violencia dictatorial era consonante con la "impronta militante” que, desde sus comienzos, había teñido la conformación del organismo (Copello, 2019).

El 20 de abril de 1977, Montoneros lanzó su nuevo espacio político con una conferencia de prensa montada en Roma, organizada en conjunto con Lelio Basso, fundador del Tribunal Russell II (encargado de juzgar crímenes de guerra) y senador del Partido Socialista Italiano. Allí presentó el MPM, que marcaba la intención de la organización de volver a filiarse con el peronismo y de elaborar, de modo más programático, una política transnacional. El MPM se asentó sobre redes y contactos políticos que, iniciados en el país, se habían formalizado en el exterior. Era el emergente de un proceso que no puede entenderse sin considerar la dimensión internacional que había adquirido la política montonera desde fines de 1974.

Los "ocho puntos" de la plataforma que Montoneros dio a conocer en Roma tenían un lenguaje fundamentalmente democrático: la organización exigía la renuncia del ministro de economía, Alfredo Martínez de Hoz; la liberación de los presos políticos; el llamado a elecciones sin proscripciones de los partidos; la rehabilitación de la Confederación General del Trabajo y la desarticulación de los "campos clandestinos" (MPM, 1977). Por primera vez, Montoneros planteaba un lenguaje explícitamente humanitario en un documento partidario: el punto seis exigía la "Eliminación inmediata de los procedimientos represivos que implican la sistemática violación de los derechos humanos” (MPM, 1977). Esta demanda indicaba, como mínimo, el interés de Montoneros de visibilizar la denuncia en clave humanitaria como parte de su nueva estrategia política. ${ }^{17}$

Esta intención también se observa en la extracción política de los consejeros del recientemente fundado MPM, ligados en algunas ocasiones a las redes de denuncia de las violaciones a los derechos humanos. 
Estos son los casos, por ejemplo, de Massaferro y Adriana Lesgart, responsables de la "Rama Femenina". Ambas tenían amplio recorrido en la política denuncialista. ${ }^{18}$ Massaferro, cuyo vínculo con la CADHU desarrollamos en el apartado previo, llegó incluso a tener una doble adscripción entre este organismo, donde formaba parte del Consejo Directivo, y el flamante MPM. Algo similar ocurrió con Puiggrós. Luego del lanzamiento de la nueva propuesta montonera, pasó a dirigir la "Rama de Intelectuales y Profesionales" del MPM sin perder su lugar en la mesa directiva del COSPA (Acha, 2006).

Este contexto político, que parecería haber concedido una relevancia mayor a quienes participaban de las redes de denuncia y solidaridad, contrastó con el intento de disciplinamiento sobre los militantes exiliados que provocó la llegada de la Conducción al exterior. Como consecuencia de este arribo, la estructura política en Ciudad de México fue reorganizada y centralizada. Montoneros abrió una sede partidaria en la capital mexicana, la Casa Montonera, y delimitó más claramente sus tres circuitos políticos: el denuncialista, que articulaba las relaciones entre el COSPA, la CADHU, ${ }^{19}$ y otros actores del exilio como el COSOFAM; ${ }^{20}$ el partidario y el clandestino, que incluían las actividades políticas y político-militares respectivamente. Esta reorganización generó nuevos focos de tensión, sobre todo en las redes que algunos militantes montoneros habían trazado con integrantes de otros organismos en el exterior (Confino, 2018). ${ }^{21}$

Si la CADHU, sin aparente contradicción con su política humanitaria, vehiculizaba un discurso que no prescindía de sus marcas combativas, Montoneros sumaba a su lucha por la revolución, por primera vez en abril de 1977, el lenguaje de respeto a los derechos humanos. Esto nos permite suponer que para entonces las diferencias entre "la revolución" y "los derechos humanos" aún no estaban tan claras para los protagonistas del proceso histórico.

La dictadura argentina acusó recibo de las denuncias hechas en el extranjero por las organizaciones de exiliados y, en un contexto en el que sería anfitriona del Mundial de fútbol previsto para junio de 1978, buscó contrarrestarlas a través de una "guerra informativa", por un lado, y de operaciones represivas en el exterior para capturar a los dirigentes guerrilleros, por el otro. El régimen militar conceptualizó las acciones de los exiliados como una "campaña antiargentina" y entendió que las políticas de denuncia y solidaridad eran el correlato de la "merma recibida en [la] capacidad operacional" de "la subversión" (DIPPBA, 1977, pp. 98-100) luego de más de un año de represión estatal y exterminio. La constitución del Centro Piloto en París entre marzo y julio de 1977, como parte de una reforma más amplia en la Cancillería controlada por la Marina, daba cuenta de la preocupación de los altos mandos militares por la difusión internacional de las denuncias contra la dictadura (Franco, 2008; Fernández Barrio y González Tizón, 2020).

El año 1978 también fue testigo de las acciones represivas extraterritoriales de parte de la dictadura. ${ }^{22}$ En enero, el Ejército secuestró en Mar del Plata a un dirigente montonero, Tulio Valenzuela, quien simuló su colaboración con un plan para secuestrar a la Conducción de su organización. Llevado a México en forma clandestina, logró escapar de los integrantes del grupo de tareas y denunció la operación. Montoneros aprovechó el acontecimiento para difundir internacionalmente el hecho: Valenzuela dio una conferencia de prensa y el MPM circuló su testimonio. El relato, publicado el 18 de enero de 1978, tramaba la denuncia de su experiencia de prisionero con numerosas referencias a la lucha revolucionaria montonera. Valenzuela era presentado como un "compañero" y "oficial mayor del Partido Montonero" que "en una heroica y brillante maniobra de contrainteligencia logró burlar al enemigo que lo tenía prisionero y denunciar al mundo" (MPM, 1978a). El proceso político era enmarcado como una guerra, aunque esto no impedía la denuncia de las condiciones del cautiverio.

También en enero de 1978 tenía lugar en París el primer plenario de la CADHU, donde Gustavo Roca, Lidia Massaferro, Eduardo Duhalde y Rodolfo Mattarollo se reunieron para realizar un balance de los dos años de funcionamiento del organismo. Más allá de que plantearan que la CADHU era el "único organismo de denuncia y solidaridad con existencia real y la única organización reconocida a nivel internacional" (CADHU, 1978a), los participantes del plenario estaban preocupados por la excesiva carga de tareas que había recaído sobre los miembros del organismo en el exilio. En la reunión parisina se afirmaba que, 
desde el operativo de secuestro de junio de 1977, la CADHU había quedado circunscripta a su delegación Internacional que, no obstante, también se había ido desarticulando con el paso del tiempo. ${ }^{23}$ Del mismo modo, sostenían que, por la gran represión sufrida, las actividades del organismo se habían regido hasta ese momento según un patrón de "dispersión organizada" en las distintas ciudades donde contaba con representantes (CADHU, 1978a). ${ }^{24}$ De cara al futuro, la propuesta era ampliar la cantidad de integrantes para realizar de un modo más eficiente sus tareas de solidaridad y denuncia.

El vínculo entre la CADHU y las organizaciones armadas también fue tema del plenario. En los registros escritos del cónclave se puede observar la preocupación, por parte de los asistentes, de quedar públicamente ligados a la plataforma política guerrillera. Pese a este temor, los miembros del organismo convalidaban como un logro haber evitado el "encasillamiento partidario" más allá del "origen inocultable de sus miembros" (CADHU, 1978a). ${ }^{25} \mathrm{Al}$ mismo tiempo que reconocían internamente la ligazón que los acercaba a las organizaciones revolucionarias -que en algunos casos era producto de trayectorias políticas compartidas a lo largo de los años y en otros consecuencia de la participación en las mismas redes de denuncia-, en el plenario se daba cuenta de lo extendida que estaba esta información entre los actores de la época. Hacia allí, de hecho, había apuntado la campaña de desprestigio de la dictadura sobre la CADHU, definiéndola como un "organismo de la guerrilla". ${ }^{26}$ Como sea, para los asistentes al plenario, los vínculos de los integrantes de la CADHU con la política revolucionaria no eran, ni en el terreno de la concepción ni en el de la práctica, un impedimento para sus tareas de denuncia y de solidaridad: "aunque la CADHU tenga representación partidaria, no debe ni puede ser una organización partidaria”. A futuro, proponían, la denuncia no debía "bajar el tono", debía ser "global” y "sin interferencias partidarias". También planteaban una solidaridad "sin limitaciones políticas e ideológicas" ni "sectarismos y exclusiones" (CADHU, 1978a).

Además de la de Valenzuela, durante 1978 se conocieron otras dos denuncias de militantes montoneros que habían logrado escapar del cautiverio clandestino: Horacio Maggio y Jaime Dri. Mientras la organización diseñaba sus actividades para el Mundial, el primero detallaba en abril, apenas fugado de la ESMA, su experiencia a manos de la Armada. Maggio envió su escrito a la CADHU para su circulación pública, lo cual deja en evidencia las tramas compartidas entre ambas organizaciones (Maggio, 1978). La denuncia de Jaime Dri, que se había escapado de sus secuestradores en la frontera de Argentina con Paraguay, sería publicada por la Secretaría de Prensa del MPM en septiembre de $1978 .{ }^{27}$ Ambos testimonios apelaban a la retórica revolucionaria de la denuncia de Valenzuela, pero adoptaban, de modo explícito, el lenguaje de respeto a los derechos humanos. Maggio sostenía que "las condiciones en las que desarrollábamos nuestras vidas [eran] dignas de la época anterior a la Asamblea del año XIII” (Maggio, 1978, p. 1), mientras que Dri explicitaba cómo el régimen había buscado "desinformar a la comunidad internacional acerca de las violaciones a los derechos humanos en la Argentina” (MPM, 1978c, p. 6). En estas intervenciones, la dictadura ya no era un contendiente bélico sino un régimen que propiciaba el terrorismo de Estado y que atacaba los derechos humanos más fundamentales. ${ }^{28}$ De este modo, a lo largo de 1978, mientras difundía sus políticas a propósito del Mundial, Montoneros formó parte de las redes de denuncia en el extranjero. ${ }^{29}$

En octubre de 1978, la Conducción de Montoneros decidió el inicio de la Contraofensiva Estratégica. La declaración previa del "triunfo de la resistencia" proponía que estaban dadas las circunstancias para un retorno organizado al país a fin de realizar actividades políticas, propagandísticas y militares que desestabilizaran a la dictadura. En lo inmediato, el inicio de la operación implicó que integrantes de la organización visitaran distintas ciudades del exilio para convocar a quienes estaban viviendo allí (Falcone, 2001; Astiz, 2005). La Contraofensiva fue un fracaso: casi un centenar de montoneros fueron víctimas de la dictadura y no se lograron los resultados políticos que había pronosticado la Conducción. Como si eso fuera poco, tal como analizaremos en el próximo apartado, durante su desarrollo se produjeron dos disidencias que dejaron a la organización al borde de la extinción. 
Un mes antes del comienzo de la Contraofensiva, el MPM instó por medio de una comunicación partidaria que llevaba la firma de Fernando Vaca Narvaja, secretario de Relaciones Exteriores de la organización, a que los militantes ocupados en tareas de solidaridad se ajustaran a la estrategia de la Conducción. En un documento dirigido "a los compañeros del MPM a cargo de comités de Solidaridad", Montoneros explicitaba su intención de lograr un mayor peso - pero sobre todo una mayor homogeneidad y centralización - en las tareas de denuncia y solidaridad que se realizaban en el exilio (MPM, 1978b). ${ }^{30}$ El lenguaje, humanitario en sus formas, tenía como fin último el reconocimiento de la legitimidad de la "resistencia del pueblo argentino". Si bien las tareas de control de la política denuncialista le cabían al propio MPM, que debía "Centralizar el trabajo en organismos como las Naciones Unidas, la Comisión de Derechos Humanos de la OEA (...) y el Parlamento Europeo", el documento también se extendía sobre el vínculo entre la organización y la CADHU. En este sentido, apuntaba a "reformular y ordenar nuestra política para organismos como la CADHU, que han alcanzado un nivel de reconocimiento importante en el plano internacional pero que aún no cubre todas las expectativas y necesidades de la política de solidaridad" (MPM, 1978b). Estas directivas dejaban nuevamente en evidencia el vínculo político de Montoneros con la CADHU al mismo tiempo que señalaban la consonancia entre los diagnósticos de la organización y la "reestructuración" que dicho organismo había encarado en enero de 1978.

Entre la publicación en Madrid de Argentina: proceso al genocidio, en marzo de 1977, y el inicio de la Contraofensiva en octubre de 1978 se articuló en el exilio un espacio común de denuncia, que involucró, entre un amplio y heterogéneo conjunto de actores, a la CADHU y a Montoneros. En algunos casos, incluso, sus iniciativas fueron consonantes, independientemente de que las ideas de revolución no siempre resultaran concordantes con las que postulaban el respeto a los derechos humanos. ${ }^{31}$ Sin embargo, estas diferencias no impidieron que, por fuera de las esferas dirigentes de Montoneros -que continuaban pensando la lucha política como una guerra- se tejiera una misma red por la que circularon las denuncias y sus impulsores. Este precario equilibrio del exilio se quebraría con el comienzo de la Contraofensiva. ${ }^{32} \mathrm{~A}$ partir de entonces, tal como veremos en el siguiente apartado, las necesidades de la denuncia y los requerimientos de la revolución no harían sino distanciarse.

\section{DERECHOS HUMANOS Y REVOLUCIÓN}

El año 1979 marcó un punto de inflexión en la oposición política a la dictadura. Durante su transcurso coexistieron las últimas expresiones de la lucha armada en la Argentina, con el desarrollo de la fallida Contraofensiva de Montoneros, y también la consolidación de la denuncia internacional de las violaciones a los derechos humanos que se producían en el país, cuyos hitos más relevantes fueron la visita de la CIDH y la presentación del llamado "testimonio de París" organizada por la CADHU en la Asamblea Nacional Francesa, en los meses de septiembre y octubre respectivamente. En abril, por su parte, había tenido lugar en la Argentina la primera huelga general en contra del régimen militar y de las políticas económicas de su ministro de economía, José Alfredo Martínez de Hoz. No obstante, la principal preocupación de la Junta hacia 1979 tenía que ver con el movimiento exiliar de denuncia, y, estrechamente vinculado a la actividad de este, con la visita de la CIDH prevista para septiembre. A prepararse para la llegada del organismo internacional dedicó la Junta Militar buena parte de sus esfuerzos desde por lo menos el mes de agosto (Canelo, 2016).

Para Montoneros, el año 1979 también fue decisivo. El desarrollo de la Contraofensiva, que incluyó transmisiones clandestinas de proclamas partidarias y atentados militares contra los funcionarios económicos del gobierno dictatorial, no tuvo las repercusiones políticas deseadas. A pesar de que la Conducción quiso hacer una lectura optimista del resultado de la estrategia, lo cierto es que, luego de la Contraofensiva, la ya duramente golpeada organización quedó al borde de su desarticulación total. ${ }^{33}$ Más aún por las dos disidencias que atravesó en ese tiempo, una antes del retorno organizado, a principios de 1979, y otra después, 
en diciembre de ese año. La primera escisión fue en febrero y se hizo pública a través del comunicado que publicaron los “oficiales montoneros" Rodolfo Galimberti y Juan Gelman en el diario parisino Le Monde (BDIC, 1979). Si en un principio habían convalidado el inicio de la Contraofensiva (Galimberti incluso había convocado a otros militantes que estaban exiliados en distintas ciudades de Europa), la proximidad del retorno a la Argentina y desavenencias más longevas entre Galimberti y la Conducción en materia de estrategia política y de disponibilidad de recursos provocaron la ruptura (Slipak, 2017).

La segunda disidencia comenzó en diciembre de 1979, cuando un grupo de militantes publicó en España el llamado "Documento de Madrid", donde se criticaba el balance que la Conducción había hecho de los resultados de la Contraofensiva de 1979. En una muestra de las tensiones y contradicciones que horadaban a Montoneros en esa coyuntura, los autores del escrito se mostraban en contra de la persistencia en el accionar militar: en sus palabras, el recurso a las armas "conspiraba contra la campaña de derechos humanos que Montoneros había motorizado en el exilio", ya que posibilitaba que la Junta Militar los señalara como terroristas (PMA, 1979). ${ }^{34}$ Entre los críticos se encontraban Jaime Dri, cuya denuncia del cautiverio el MPM había circulado en 1978, y Pablo Ramos, miembro de la CADHU desde las etapas formativas del organismo. Sin posibilidad de acuerdo, en abril de 1980 se presentaba en México el nuevo agrupamiento de los disidentes: Montoneros 17 de octubre.

En su manifiesto fundacional, los miembros del flamante espacio sentaban públicamente las bases de su plataforma. Uno de los puntos salientes del documento era el que postulaba la necesidad de dejar de entender el conflicto político como una "guerra", y proponía, en cambio, retomar el concepto de "rebeldía popular" (M17, 1980). Esta propuesta, que implicaba una sustancial transformación en el paradigma montonero, no puede entenderse sin las transformaciones políticas que habían acaecido durante esos años en el exilio: a la recuperación de la "rebeldía" por los disidentes, le seguía la consideración de la dictadura ya no como un ejército de ocupación en su propio país, según la habían definido en varias oportunidades los documentos montoneros, sino como un régimen político que ejercía la sistemática violación de los derechos humanos a través del terrorismo de Estado. Más cerca de la política "denuncialista" que de la ambición revolucionaria, la intervención de Montoneros 17 de octubre confluía, sin resignar la revolución como horizonte final, con los cambios del contexto (Confino, 2018).

Las transformaciones en la coyuntura política que rodearon al año 1979 también tuvieron su impacto en la CADHU, aunque en un sentido inverso al que provocaron en Montoneros. Hacia finales de 1978, la combinación de la noticia de la futura visita de la CIDH y el pase a retiro del almirante Massera, concretado en el mes de septiembre, iniciaron una serie de transformaciones en el CCD de la ESMA. Una de las más significativas, a tono con la impronta legalista de la que pretendía revestirse el ex jefe de la Armada ante la comunidad internacional, fue la liberación de un conjunto de militantes montoneros que habían atravesado un cautiverio prolongado en manos de los marinos. Todos ellos pertenecían al conjunto de secuestrados que por sus conocimientos técnicos o su jerarquía política había sido incorporado al "proceso de recuperación" ideado por el jefe del grupo de tareas (GT) de la ESMA, Jorge "el Tigre" Acosta (Feld y Franco, 2019). Como condición para su liberación, los marinos los obligaron a abandonar la Argentina, instrumentando incluso los medios necesarios para su salida hacia el extranjero. España, Francia, Venezuela y, en menor medida, Ecuador y Brasil fueron los destinos que inicialmente albergaron a las sobrevivientes y los sobrevivientes (González Tizón, 2019a).

A pesar de las amenazas que les profirieron sus captores, el destierro significó para varias de las liberadas y los liberados de la ESMA el retorno a la actividad política. Los recién llegados pronto se insertaron en las tramas militantes desarrolladas por los exiliados argentinos en los distintos países de acogida. Sus actitudes respecto a Montoneros fueron disímiles aunque, en general, la tendencia se inclinó hacia el alejamiento de la organización. Tampoco esta se mostró receptiva hacia las sobrevivientes y los sobrevivientes: el cautiverio prolongado en manos de los marinos, sumado al conocimiento de la presencia de algunos agentes represivos en distintas plazas del exilio, incentivó las sospechas sobre las militantes y los militantes liberados. Sin 
embargo, estos desencuentros no dieron lugar a polémicas resonantes, ni, al menos inicialmente, a una ruptura total entre esos sobrevivientes y el espacio montonero. Las condiciones de posibilidad para el encuentro político de ambos las aportó la CADHU. En ello jugaron un rol destacado las redes de contactos desarrolladas por sus sedes en Madrid y París, y, también, las gestiones individuales de algunos de sus militantes.

España se convirtió en el punto de confluencia de la mayoría de las sobrevivientes y los sobrevivientes de la ESMA con pasado en Montoneros: a quienes se habían instalado allí desde un comienzo se sumó, en el transcurso de 1979, otro contingente procedente de Francia y de Venezuela. ${ }^{35}$ Este núcleo, conformado por una decena de personas, comenzó a proyectar la posibilidad de elaborar un testimonio colectivo de su experiencia en la ESMA. ${ }^{36}$ Los extensos períodos de cautiverio, en promedio superiores al año, y las tareas desempeñadas en el marco del "proceso de recuperación" habían permitido a estos sobrevivientes adquirir un conocimiento de los actores y las dinámicas del CCD inaccesible para el resto de las y los secuestrados. La combinación de este saber y de sus capitales políticos, reactivados al entrar en contacto con las tramas militantes del exilio, generaba las condiciones para un testimonio de la represión clandestina de una envergadura desconocida hasta entonces. La CADHU, que entonces había logrado construir una legitimidad considerable en el ámbito humanitario europeo, vehiculizó la puesta en acto del proyecto, cuyo resultado fue la presentación de las tres mujeres sobrevivientes de la ESMA ante la Asamblea Nacional francesa.

La reconstrucción del entramado de vínculos que sustentó la elaboración del "testimonio de París" no es sencilla y contiene varios puntos ciegos, sobre todo en lo que refiere al rol que le cupo a Montoneros en su realización. No obstante, el recuerdo de algunos protagonistas ofrece indicios sobre las relaciones entre la organización armada peronista, la CADHU, las sobrevivientes y los sobrevivientes. Massaferro, quien combinaba su labor en el organismo de derechos humanos con su actividad como miembro del Consejo Superior del MPM, surge como una figura clave en la articulación entre las partes: "creo que todos habíamos hablado por distintas razones con Lili Massaferro, que era una mujer a la cual nosotros conocíamos, una tipa que fue solidaria con nosotros", recuerda Alicia Milia, una de las testimoniantes en París (González Tizón, 2019b). La afirmación va en sintonía con el hecho de que, para entonces, Massaferro había abandonado Italia para instalarse en España, desde donde llevó adelante constantes viajes a distintos puntos de Europa para motorizar la denuncia de los crímenes de la dictadura. ${ }^{37}$ Estas gestiones le permitieron, entre otras cosas, entablar un vínculo estrecho con Theo Van Boven, director de la división de Derechos Humanos de la ONU. ${ }^{38}$

La elaboración del testimonio propiamente dicho se llevó adelante a lo largo de varios meses en distintos puntos de España. Entonces, las sobreviviente y los sobrevivientes todavía eran vigilados por los oficiales de la ESMA, quienes pretendían de este modo impedir una eventual denuncia en el exilio. ${ }^{39} \mathrm{~A}$ pesar de las amenazas, se las ingeniaron para realizar las primeras reuniones a fin de discutir el contenido del relato, que tendrían como sede la localidad de Culleras, un pequeño pueblo de playa cercano a Valencia, donde se habían instalado Sara Solarz y Ana María Martí: "ahí marchó toda la pandilla a la casita de Culleras, que no sabíamos ni dónde quedaba, y ahí estuvimos y discutimos”, rememora Milia (González Tizón, 2019b). Luego, los encuentros se trasladaron a Madrid, ya con el objetivo de llevar adelante la redacción del testimonio. Hasta esa ciudad llegaron, en los primeros días de octubre, Graciela Daleo y su pareja de ese momento, procedentes de Venezuela. Su presencia en el lugar no era casual, sino que se inscribía en parte en el proyecto del testimonio, cuyas gestiones alcanzaban una dimensión transnacional: "cuando nosotros llegamos ya estaba lanzado, por eso también nos apuraron para que nosotros viajáramos", afirma Daleo (González Tizón, 2019a). Reunido en un apart hotel de la capital española, un grupo más reducido se abocó a la producción del escrito que contendría el recuerdo colectivo de su paso por la ESMA. ${ }^{40}$

Las gestiones que permitieron realizar el testimonio en París permanecen como un punto oscuro de la historia: ¿̨las llevó adelante la CADHU, Montoneros o ambos? El rol del organismo de derechos humanos resulta insoslayable: no solo lo reconocen los propios protagonistas del evento - "yo me acuerdo de haber 
estado con Eduardo [Duhalde] y con [Gustavo] Roca y (...) el abogado, [Manuel] Gaggero”, afirma Milia-, sino que su participación quedó grabada en la versión escrita del testimonio, donde figuraba el sello de la CADHU. ${ }^{41}$ Por otra parte, la presencia de Montoneros en las negociaciones previas al testimonio parece innegable, a tal punto que fue dada por sentada en más de una ocasión (Franco, 2008; Jensen, 2010). No solo la sugieren la trama de vínculos compartida con la CADHU y las sobreviviente y los sobrevivientes de la ESMA; también lo hace el antecedente de la conferencia de prensa organizada en 1978 donde Dri hizo público su relato del cautiverio clandestino, resultado de un acuerdo entre Montoneros y el Partido Socialista de Francia. ${ }^{42}$ Más allá de estos indicios, lo cierto es que no hay ninguna evidencia concreta de la participación de la organización armada peronista en el "testimonio de París", cuestión que permanece en el plano hipotético incluso para los protagonistas del evento. Al ser consultada al respecto, Milia afirma sin rodeos que "lo bancó la CADHU", aunque enseguida añade que "eso yo creo que sí lo negoció con la organización Montoneros" (González Tizón, 2019b.

El 12 de octubre, el testimonio fue presentado en la conferencia de prensa organizada en París. Junto a las tres sobrevivientes, que habían llegado al lugar protegidas por la custodia personal de François Mitterrand, estaba en el escenario Stasi. Frente a ellos se situaban periodistas de diversos medios acreditados al evento. La elección del lugar había sido estratégica. Francia era una especie de "patria de los derechos humanos" y lo que ocurría allí resonaba en el resto del mundo occidental (Franco, 2008). A su vez, la Asamblea Nacional constituía un centro neurálgico de la vida política, donde confluían representantes de distintas extracciones ideológicas. El momento, por otra parte, no podía ser mejor a los fines de la denuncia: la visita de la CIDH, finalizada el 20 de septiembre, había puesto los ojos de la comunidad internacional en la Argentina (Jensen, 2010). A partir de estos elementos, no resulta difícil comprender por qué el testimonio resonó rápidamente más allá de Francia. ${ }^{43}$

La presentación de las tres sobrevivientes fue rotunda en su denuncia de las violaciones a los derechos humanos en la Argentina. La caracterización de la represión dictatorial como un "genocidio", en línea con el informe de la CADHU de 1977, se acompañó de acusaciones sobre la responsabilidad institucional de las Fuerzas Armadas en el accionar clandestino y acerca del asesinato planificado de la mayoría de los desaparecidos. ${ }^{44}$ La versión escrita del testimonio ofrecía a lo largo de sus casi cien páginas el detalle de las vivencias durante el cautiverio en la ESMA, e incluía también planos del CCD y listados de personas secuestradas y de integrantes del GT. Si bien la descripción de los padecimientos estaba impregnada de un lenguaje humanitario, el texto poseía también numerosas marcas de la sensibilidad revolucionaria: la más significativa era el reconocimiento explícito que hacían las tres sobrevivientes de su militancia montonera previa al secuestro. ${ }^{45}$ Esta convivencia entre el lenguaje de la revolución y el de los derechos humanos, ajena a los moldes preestablecidos de la denuncia internacional, constituía la muestra acabada de la diversidad de actores y tradiciones que habitaban al "testimonio de París" y a sus protagonistas.

\section{Reflexiones Finales}

La década de 1980 albergó en su seno el ocaso definitivo de los proyectos revolucionarios argentinos, y el apogeo de la denuncia internacional y en clave humanitaria de los crímenes dictatoriales. Este proceso catapultó al movimiento local de derechos humanos como un actor central de la transición democrática que se abrió en el país luego de la finalización de la Guerra de Malvinas en junio de 1982 (Franco, 2018). No obstante, antes de evidenciar ese hiato, y tal como lo hemos mostrado a lo largo del artículo, la política revolucionaria y su par humanitaria hallaron, entre fines de 1976 y principios de 1980, un espacio político de articulación - no exenta de conflictos- en su tarea de oposición a la dictadura. Este ámbito común tuvo en la denuncia de los crímenes dictatoriales y en la solidaridad con los argentinos y argentinas que llegaban al 
exilio un acuerdo básico e incluyó, en distintas proporciones pero componiendo redes comunes, a organismos humanitarios como la CADHU y a organizaciones revolucionarias como Montoneros.

A través del análisis de los vínculos entre Montoneros y la CADHU, y el espacio político que ambos entretejieron en el exterior, este trabajo buscó sugerir una nueva puerta de entrada para estudiar las redes del activismo exiliar y las transformaciones políticas que alumbró el segundo lustro de la década de 1970, mientras maduraba la derrota del proyecto revolucionario y surgían nuevas formas de intervención política ligadas al discurso y la acción humanitarias. Antes de que este proceso estuviera completo, se dieron en el exterior puntos de acuerdo que indican que, en la práctica, para muchas de las protagonistas y los protagonistas de esa experiencia el deseo revolucionario no era contradictorio con la denuncia de las violaciones a los derechos humanos en los foros internacionales.

En un plano más general, sostenemos que la constitución de una oposición política transnacional a la dictadura fue posible, entre otras cuestiones, gracias a las redes construidas en el exterior por las organizaciones armadas. Esto nos lleva a afirmar, a su vez, que las fronteras que se construyeron entre "revolución" y "derechos humanos" a lo largo de la década de 1980 no se corresponden necesariamente con la fisonomía del proceso histórico, al menos para el período 1976-1980. El caso analizado permite apreciar la constitución de un movimiento de oposición al régimen militar en el exilio, que se estructuró a través de redes comunes a organismos humanitarios y organizaciones insurgentes.

Las prácticas de denuncia y solidaridad en el exilio crecieron a medida que la represión en la Argentina también lo hizo. Montoneros logró hegemonizar un primer comité de denuncia y solidaridad en México, entre fines de 1975 y principios de 1976. Con el golpe de marzo, ante el aumento exponencial de la represión y la ineficacia de las recetas políticas aplicadas, la organización decidió trasladar al extranjero el resto de su aparato político. Al mismo tiempo que perdía inserción en la Argentina y sufría asesinatos y desapariciones por parte del gobierno dictatorial, Montoneros lanzaba su nuevo espacio en Roma, en el que explicitaba su intención de incorporar la denuncia humanitaria como parte de su plataforma.

El proceso que atravesó la CADHU fue análogo en ciertos aspectos. Desde sus orígenes, el organismo contó entre sus filas con militantes de diferentes extracciones políticas, entre los que se incluían algunos vinculados a las organizaciones político-militares. Nombres como Gaggero, Mattarollo, Massaferro o Ramos evidencian las conexiones con el PRT-ERP y Montoneros. Conexiones que, por otra parte, resultaron fundamentales para obtener información sobre el accionar criminal de la dictadura, y, así, llevar adelante la actividad de denuncia. De manera similar a lo que ocurrió con esas organizaciones, el peso de la represión también obligó a la CADHU a trasladar progresivamente su funcionamiento al exilio, hecho que se consumó a mediados de 1977 con la desaparición y asesinato del núcleo de militantes del PROA en el país.

El "testimonio de París", a la vez que puso en acto las redes construidas previamente entre Montoneros y la CADHU, marcó un punto de quiebre en la trayectoria de ambas organizaciones, cuyos derroteros posteriores se bifurcarían cada vez más. Por el lado de la CADHU, con su sede de Madrid y la figura de Duhalde a la cabeza del organismo, la tendencia sería hacia una mayor confluencia con el movimiento transnacional de derechos humanos, proceso que se evidenciaría, por ejemplo, en sus presentaciones recurrentes ante el flamante Grupo de Trabajo sobre Desapariciones Forzadas y Voluntarias de la ONU, creado en Ginebra en febrero de 1980. En lo que concierne a Montoneros, las dos disidencias padecidas y el fracaso de la Contraofensiva de 1980 desembocarían en la pérdida de toda su relevancia política. De allí en más, su prédica quedaría confinada a la que sería su última publicación partidaria, Vencer, editada entre 1980 y 1982. Como un síntoma de época, la revista dedicaría cada vez mayor espacio a las acciones de las Madres de Plaza de Mayo, para entonces ya consagradas a nivel internacional como el emblema de la lucha por los derechos humanos en la Argentina.

Había iniciado otra etapa en la historia de la oposición a la dictadura, una en la que la prédica humanitaria no daría cabida a las expresiones revolucionarias armadas, desprestigiadas en el terreno de la denuncia. La posdictadura, en su intento de ruptura total con la violencia pasada, no haría sino consolidar ese estado de 
cosas. El movimiento de derechos humanos se desembarazaba así de una parte significativa de las redes que lo habían constituido.

\section{FUENTES DOCUMENTALES}

\section{Entrevistas}

Confino, Hernán (2014). Entrevista a Daniel Cabezas, Buenos Aires, 3 de noviembre.

Confino, Hernán (2016a). Entrevista a César Calcagno, Buenos Aires, 25 de agosto.

Confino, Hernán (2016b). Entrevista a Carlos González Gartland, Buenos Aires, 30 de noviembre.

Confino, Hernán (2016c). Entrevista a Roberto Perdía, City Bell, Provincia de Buenos Aires, 14 de diciembre.

González Tizón, Rodrigo (2019a). Entrevista a Graciela Daleo, Buenos Aires, 4 de junio.

González Tizón, Rodrigo (2019b). Entrevista a Alicia Milia, Buenos Aires, 17 de junio.

Archivo Nacional de la Memoria (2020). Entrevista a Horacio Lofredo, Buenos Aires-Ecuador, abril-julio. Memoria Abierta (2003a). Entrevista a Carlos González Gartland, Buenos Aires, 8 y 13 de noviembre.

Memoria Abierta (2003b). Entrevista a Manuel Gaggero, Buenos Aires, 17 y 24 de noviembre y 19 de diciembre.

Memoria Abierta (2003c). Entrevista con Rodolfo Mattarollo, Buenos Aires, 15 de noviembre y 20 de diciembre.

\section{DOCUMENTOS PARTIDARIOS (DISPONIBLES EN WWW.ELTOPOBLINDADO.COM)}

BDIC (1979). Anexo: Versión completa del comunicado que extracta 'Le Monde' del 25-2-79, Nanterre Cedex, Francia.

CADHU (1976). Declaración de principios, 10 de diciembre.

CADHU (1977). Argentina: proceso al genocidio, Madrid.

CADHU (1978a). Reestructuración, Madrid.

CADHU (1978b). Programa: Buro de Información Europeo de la Comisión Argentina de Derechos Humanos, París, 21 de abril.

CADHU (1979). Testimonios de los sobrevivientes del genocidio en la Argentina, octubre.

COSPA (1977). Carta a la CADHU, México, 18 de agosto.

Desclasificados EEUU (1979). Report to Defense Intelligence Agency. Human Rights-Argentina Prepares for OAS Human Rights Comission Visit. 25 enero. Agencia de Inteligencia de la Defensa. Disponible en Archivo Nacional de la Memoria.

DIPPBA (1977). Mesa D “(e)”, factor social por localidad, legajo 253. Capital Federal.

Evita Montonera (1977a). N¹5, febrero.

Evita Montonera (1977b). $\mathrm{N}^{\circ} 16$, marzo.

Evita Montonera (1977c). $\mathrm{N}^{\circ} 23$, enero.

González Gartland, Carlos (1978). Carta a Rodolfo Matarollo, México, 16 de agosto.

Montoneros (1978). Boletín Interno, $\mathrm{N}^{\circ} 8$, octubre

Montoneros (1980). Boletín Interno, $\mathrm{N}^{\circ} 13$, febrero.

MPM (1977). Documento de Roma, abril.

MPM (1978a). Testimonio de Edgar Tulio Valenzuela, 18 de enero.

MPM (1978b). Secretaría de Relaciones Exteriores, 12 de septiembre.

MPM (1978c). Testimonio de Jaime Dri.

PMA (1979). Documento de Madrid, Madrid, diciembre. 
M17 (1980). s/t, abril.

Presencia Argentina (1979). No 2, Madrid, diciembre.

Sala de Representantes de los Estados Unidos (1976). Audiencias ante subcomité de Organizaciones

Internacionales, Segunda Sesión, 28-29 de septiembre.

Horacio Maggio (1978). Testimonio dirigido a la CADHU, 10 de abril.

\section{REFERENCIAS}

Acha, O. (2006). La nación futura. Rodolfo Puiggrós en las encrucijadas argentinas del Siglo XX. Eudeba: Buenos Aires.

Alonso, L. (2017). Terror de Estado y luchas pro derechos humanos en Argentina: las dimensiones ocluidas. Revista Ayer, 107 (3). Recuperado de https://revistaayer.com/articulo/164

Astiz, E. (2005). Lo que mata de las balas es la velocidad: una historia de la contraofensiva montonera de 1979. La Plata: De la Campana.

Baschetti, Roberto. (2001). Documentos 76/77. Golpe Militar y resistencia popular. La Plata: De la Campana.

Besoky, J. L. (2016). Violencia paraestatal y organizaciones de derecha. Aportes para repensar el entramado represivo en la Argentina (1970-1976). Nuevos Mundos Mundos Nuevos. Recuperado de https://journals.openedition.or g/nuevomundo/68974

Calderoni, G. (2017). Les exilés argentins en Italie (1974-1983), Tesis de Maestría inédita. Université Sorbonne Nouvelle-París 3.

Canelo, P. (2016). La politica secreta de la última dictadura militar argentina (1976-1983). Buenos Aires: Edhasa.

Carnovale, V. (2011). Los combatientes: historia del PRT-ERP. Buenos Aires: Siglo XXI.

Carnovale, V. (2014). El PRT-ERP en el exilio. Armas, comunismo y derechos humanos. Revista de Historia, 15. Recuperado de http://revele.uncoma.edu.ar/htdoc/revele/index.php/historia/article/view/868/900

Casola, N. (2014). Una valija y un carnet. El lugar del Partido Comunista en el exilio argentino. En S. Jensen y S. Lastra (Eds.), Exilios: militancia y represión. Nuevas fuentes y nuevos abordajes de los destierros de la Argentina de los años setentas (pp. 41-70). La Plata: Edulp. Recuperado de https://memoria.fahce.unlp.edu.ar/libros/pm.37 1/pm.371.pdf

Chama, M. (2007). Movilización y politización: abogados de Buenos Aires entre 1968 y 1973. En Anne PérotinDumon (dir.), Historizar el pasado vivo en América Latina. Recuperado de http://etica.uahurtado.cl/historiza relpasadovivo/es_contenido.php

Confino, H. (2018). La Contraofensiva Estratégica de Montoneros. Entre el exilio y la militancia revolucionaria (1976-1980), Tesis de Doctorado, UNSAM, Buenos Aires. Recuperada de https://ri.conicet.gov.ar/handle/1 $1336 / 78815$

Confino, H. (2020). Las redes montoneras en el exilio. Revolución, solidaridad y derechos humanos (1974-1980). En G. Águila, S. Garaño y P. Scatizza (Coords.), La represión como politica de estado. Estudios sobre la violencia estatal en el siglo XX (pp. 257-270). Buenos Aires: Imago Mundi.

Copello, D. (2019). Faire la révolution par les droits de l'homme: un phénomène d'imbrication militante dans l'Argentine des années 1970 et 1980. Revue Francaise de Science Politique, Fondation Nationale des Sciences Politiques, 69 (4). Recuperado de https://hal.archives-ouvertes.fr/hal-02507484

Eidelman, A. (2009). El PRT-ERP y la lucha por la libertad de los presos políticos, 1971-1973. Sociohistórica, 25, 13-39. Recuperado de https://memoria.fahce.unlp.edu.ar/library?a=d\&c=arti\&d=Jpr4430

Falcone, J. (2001). Memorial de guerralarga. Un pibe entre cientos de miles. La Plata: De la Campana.

Feld, C. y Franco, M. (2019). Las tramas de la destrucción: prácticas, vínculos e interacciones en el cautiverio clandestino de la ESMA. Quinto Sol, 23 (3). Recuperado de https://cerac.unlpam.edu.ar/index.php/quintosol /article/view/3844 
Fernández Barrio, F. (2017). Diplomacia y represión extraterritorial: la actuación del Servicio Exterior argentino en el "caso Molfino". Avances del Cesor, XIV (16), 131-148. Recuperado de https://ojs.rosario-conicet.gov.ar/inde x.php/AvancesCesor/article/view/v14n16a06

Fernández Barrio, F. y González Tizón, R. (2020). De la ESMA a Francia: hacia una reconstrucción histórica del Centro Piloto de París (1977-1979). Folia Histórica del Nordeste, 38. Recuperado de https://revistas.unne.edu .ar/index.php/fhn/article/view/4465/4168

Franco, M. (2008). El exilio. Argentinos en Francia durante la dictadura. Buenos Aires: Siglo XXI.

Franco, M. (2012). Un enemigo para la nación. Orden interno, violencia y "subversión", 1973-1976. Buenos Aires: FCE.

Franco, M. (2018). El final del silencio. dictadura, sociedad y derechos humanos en la transición (Argentina, 1979-1983). Buenos Aires: FCE.

Garaño, S. (2015). Represión política, terror y rumores en el teatro de operaciones del Operativo Independencia (Tucumán, 1975-1977). Clepsidra, 2 (3), 46 -71. Recuperado de https://ri.conicet.gov.ar/handle/11336/51373

Gillespie, R. (1998). Soldados de Perón. Los Montoneros. Buenos Aires: Grijalbo.

Giussani, L. (2005). Buscada: Lili Massaferro: de los dorados años cincuenta a la militancia montonera. Buenos Aires: Norma.

González Tizón, R. (2016). “Cada voz que se alce puede salvar una vida en Argentina”. La producción testimonial de los sobrevivientes de los Centros Clandestinos de Detención en el marco de la Comisión Argentina por los Derechos Humanos (1979-1983). Papeles de Trabajo, 10, 162-183. Recuperado de https://revistasacademicas. unsam.edu.ar/index.php/papdetrab/article/view/670/609

González Tizón, R. (2021). “Los desaparecidos empiezan a hablar”: una aproximación histórica a la producción testimonial de los sobrevivientes de la dictadura argentina desde el exilio (1976-1983). Páginas. Revista digital de la Escuela de Historia. Recuperado de https://revistapaginas.unr.edu.ar/index.php/RevPaginas/article/view 1475

Jensen, S. (2007). La provincia flotante. El exilio argentino en Cataluña (1976-2006). Barcelona: Fundació Casa América Catalunya.

Jensen, S. (2010). Los exiliados. La lucha por los derechos humanos durante la dictadura. Buenos Aires: Sudamericana.

Jensen, S. (2014). Las fuentes de oposición exiliar y el estudio de las actitudes sociales durante el último gobierno militar en la Argentina (1976-1979). II Jornadas de Trabajo de Exilios políticos del Cono Sur en el siglo XX. Montevideo. Recuperado de https://memoria.fahce.unlp.edu.ar/library?a $=\mathrm{d} \& \mathrm{c}=$ eventos\&d=Jev3962

Jensen, S. y Lastra, S. (Eds). (2014). Exilios: militancia y represión. Nuevas fuentes y nuevos abordajes de los destierros de la Argentina de los años setenta. La Plata: Edulp. Recuperado de https://memoria.fahce.unlp.edu.ar/libros/p m.371/pm.371.pdf

Larraquy, M. (2006). Fuimos soldados. Historia secreta de la Contraofensiva montonera. Buenos Aires: Norma.

Mangiantini, M. (2017). Redes militantes y acciones en el exilio. La política internacionalista del Partido Socialista de los Trabajadores (1976-1982). Estudios, 38, 87-104. Recuperado de https://revistas.unc.edu.ar/index.php/rest udios/article/view/19130

Osuna, M. F. (2014). El exilio del Partido Socialista de los Trabajadores en Bogotá (1976-1982). Entre los discursos militantes y las miradas policiales. En S. Jensen y S. Lastra, (eds.), Exilios: militancia y represión. Nuevas fuentes y nuevos abordajes de los destierros de la Argentina de los años setentas (71-93). La Plata: Edulp. Recuperado de $\mathrm{h}$ ttps://memoria.fahce.unlp.edu.ar/libros/pm.371/pm.371.pdf

Otero, R. (2019). Montoneros y la memoria del peronismo. Buenos Aires: Prometeo.

Pozzi, P. (2004). Por las sendas argentinas. El PRT-ERP, la guerrilla marxista. Buenos Aires: Imago Mundi.

Pontoriero, E. (2016). En torno a los orígenes del terror de Estado en la Argentina de la década de los setenta. Cuándo, cómo y por qué los militares decidieron el exterminio clandestino. Papeles de Trabajo, 10(17), 30-50. Recuperado de https://ri.conicet.gov.ar/handle/11336/106010?show=full

Robledo, P. (2018). Montoneros y Palestina. De la Revolución a la Dictadura. Buenos Aires: Planeta. 
Robledo, P. (2021). La CADHU USA: una experiencia sui generis en el corazón del imperio.En Investigar en el Archivo 1: La Comisión Argentina de Derechos Humanos. Buenos Aires: Archivo Nacional de la Memoria.

Rot, G. (2015). Itinerarios revolucionarios: de la Resistencia al Partido Revolucionario de los Obreros Argentinos. La Plata: De la Campana.

Servetto, A. (2010). 73/76. El gobierno peronista contra las "provincias montoneras". Buenos Aires: Siglo XXI.

Slatman, M. (2012). Actividades extraterritoriales represivas de la Armada Argentina durante la última dictadura civilmilitar de Seguridad Nacional (1976-1983). Aletheia, 3(5). Recuperado de https://memoria.fahce.unlp.edu.ar $/$ library? $=\mathrm{d} \& \mathrm{c}=\operatorname{arti} \& \mathrm{~d}=\mathrm{Jpr} 5451$

Slipak, D. (2017). Sobre desvíos, espejos y cúpulas. Las disidencias montoneras y las lecturas sobre los años setenta. Revista Izquierdas, 32.

Santucho, J. (2004). Los últimos guevaristas. La guerrilla marxista en la Argentina. Buenos Aires: Grupo Editorial Zeta.

Solís, C. (2014). De las comisiones a los organismos en Córdoba: derechos humanos, dictadura y democratización. En R. I. Kotler (comp.), En el país del si me acuerdo. Los origenes nacionales e internacionales del movimiento de derechos humanos argentino: de la dictadura a la transición. Buenos Aires: Imago Mundi.

Yankelevich, P. (2010). Ráfagas de un exilio. Argentinos en México, 1974-1983. Buenos Aires: FCE.

\section{Notas}

1 Este recorte implica dejar de lado otros vínculos de la CADHU, como los mantenidos con el Partido Revolucionario de los Trabajadores-Ejército Revolucionario del Pueblo (PRT-ERP). No obstante, si bien no es tema central del artículo, se harán referencias puntuales a la trayectoria del PRT-ERP, sobre todo, de sus militantes que también participaron de la CADHU.

2 Es poco y fragmentario lo que hasta el momento se ha reconstruido de la trayectoria del PRT-ERP en el exilio. A los fines de este artículo, vale decir que luego del asesinato de Santucho la organización se trasladó al exterior en diciembre de 1976 y se fijó como meta partidaria el desarrollo de la solidaridad y la denuncia internacional. Como parte de esa política, el PRT-ERP tuvo mayor inserción en Francia (donde mantuvo vínculos con el Centro Argentino de Información y Solidaridad -CAIS-) y en Italia (donde estableció contacto con el Comité Antifascista contra la Represión en la Argentina -CAFRA-). En ese marco, el PRT-ERP trazó acuerdos con Montoneros para financiar y apoyar, en conjunto, a la CADHU (Carnovale, 2014).

3 Las trayectorias de los integrantes eran bastante heterogéneas. Por ejemplo, Righi había sido ministro del Interior en el gobierno de Cámpora, Jitrik era escritor y crítico literario y había participado de la revista Contorno, Obregón Cano había sido gobernador de Córdoba y Calcagno era un abogado laboralista, entre otros.

4 Según Calcagno, en paralelo al trabajo de denuncia "nos dedicamos a organizar la estructura de lo que sería después el COSPA para iniciar en México y en todo lo que se pudiera de América Latina, la denuncia contra la dictadura” (Confino, 2016a).

5 A estos agrupamientos habría que agregar la Liga Argentina por los Derechos del Hombre (LADH), organismo vinculado al Partido Comunista Argentino, cuya fundación se remonta a 1937.

6 No es sencillo establecer una fecha específica para la fundación de la CADHU. Según Carlos González Gartland, se creó en abril de 1976, información confirmada por un documento posterior del organismo (CADHU, Programa: Buro de Información Europeo de la Comisión Argentina de Derechos Humanos, París, 21 de abril de 1978). No obstante, la Asamblea Constitutiva donde se aprobaron la Declaración de Principios y el Estatuto de la CADHU -formalizando así el funcionamiento de la nueva entidad- tuvo lugar recién en julio de 1976.

7 Esta "Delegación exterior" de la CADHU estaría conformada provisoriamente por Eduardo Luis Duhalde, Rodolfo Mattarollo, Lucio Garzón Maceda, Lidia Massaferro, Gustavo Roca y Roberto Guevara. Esta inclinación sería refrendada en su "Declaración de principios", donde se planteaba la necesidad de una "ampliación y profundización de la denuncia ante Foros Internacionales” (CADHU, Declaración de principios, 10 de diciembre de 1976).

$8 \mathrm{Al}$ respecto, recuerda Gartland: "En definitiva la opción era fácil. Donde estaban los que no rechazaban la lucha armada, donde estaban los que tenían víctimas directas fundantes y significativas y que no pertenecían a un ámbito académico e intelectual, que habían tenido los materiales para huir, estaban en el COSPA" (Confino, 2016b).

9 Además de Mattarollo, en Francia también se había instalado otro miembro de la CADHU, Lucio Garzón Maceda.

10 Algunas de esas caídas afectaron seriamente el circuito de denuncia articulado junto a la CADHU: en el mes de octubre se produjo el secuestro de varios integrantes de la "Columna Oeste", vinculados al aparato de prensa de la organización, 
entre quienes se encontraba el abogado Juan Carlos Caprioli, enlace clave del organismo de derechos humanos (Rot, 2015).

11 El "exilio orgánico" de Montoneros se dio en un contexto interno convulsionado por las críticas que había recibido la conducción por la estrategia impulsada desde el pase a la clandestinidad de la agrupación, en septiembre de 1974, que había derivado en una gran cantidad de militantes secuestrados y desaparecidos (Otero, 2019).

12 Parte de este trabajo quedó registrado en las cartas que Ignacio Ikonicoff le envió a Duhalde desde Buenos Aires al exilio madrileño a través del periodista italiano Saverio Tutino, quien lograba sacarlas del país en valija diplomática. Se recuperaron un total de 16 cartas, escritas entre el 7 de septiembre de 1976 y el 4 de febrero de 1977. En ellas, Ikonicoff relataba a Duhalde la creciente situación represiva en la Argentina y lo ponía al tanto de los avances en la confección de los boletines de la CADHU que, una vez fuera del país, serían publicados por los representantes del organismo en el exilio. Fueron un total de 25 boletines, fechados entre el 7 de octubre de 1976 y el 24 de mayo de 1977 (Rot, 2015).

13 Esta primera denuncia fue seguida por otra al año siguiente ante la Comisión de Derechos Humanos de la ONU (CADHU, "Conferencia de prensa dada por la Comisión Argentina por los Derechos Humanos", Ginebra, 21 de febrero de 1977).

14 Sala de Representantes de los Estados Unidos, Audiencias ante subcomité de Organizaciones Internacionales, Segunda Sesión, 28-29 de septiembre de 1976. Se encuentra disponible una traducción de las declaraciones completas de Lucio Garzón Maceda y Gustavo Roca y del testimonio de Olga Talamante, realizada por la Coordinación de Investigaciones Históricas del Archivo Nacional de la Memoria (Archivo Nacional de la Memoria. Las declaraciones ante el Congreso de Estados Unidos y los inicios de la denuncia en el plano internacional. Washington, 28 y 29 de diciembre de 1976. Buenos Aires: Archivo en Contexto, No 1, septiembre de 2020). Disponible en: https://www.argentina.gob.ar/sites/default/file s/anm_-_archivo_en_contexto_1.pdf (última consulta: 9 de julio de 2021).

$15 \mathrm{El}$ informe estaba organizado en cinco apartados: "Estructura del Estado represor", "El Terrorismo de Estado", "La represión obrera: razón de Estado", "Epílogo" y “Testimonios y denuncias ("CADHU, Proceso al genocidio, Madrid, 1977).

16 Ídem. En este punto el diagnóstico era consonante con el que se esgrimía desde Montoneros (véase, Evita Montonera, $1977 b)$

17 Esta intención ya había sido esbozada en Evita Montonera (1977a). Sobre la conformación del MPM véase Gillespie, 1998; Confino, 2018 y Otero, 2019.

18 A principios de 1977, como parte del exilio orgánico, Lesgart marchó a Europa para ocuparse de sistematizar y ordenar las denuncias de violaciones a los derechos humanos de la dictadura. Volvió a Buenos Aires durante la Contraofensiva, donde fue secuestrada en septiembre de 1979, mientras se encontraba la CIDH en el país. Al momento de su desaparición era primera secretaria de la Rama Femenina del Consejo Superior del Movimiento Peronista Montonero, a cargo de la solidaridad con los presos políticos y sus familias (Larraquy, 2006).

19 Esta cuestión se observa, por ejemplo, en la correspondencia que el COSPA mantuvo con la CADHU a lo largo del período investigado. En particular, los intercambios buscaban articular e institucionalizar la labor de denuncia, mantenida entre México y Europa (Carta del COSPA a la CADHU, agosto de 1977). Además, la CADHU cultivó relaciones con diferentes organizaciones no gubernamentales, algunas con inserción en las Naciones Unidas, como la Federación Internacional de Derechos Humanos, la Comisión Internacional de Juristas, la Federación de Juristas Católicos, Pax Romana, Amnesty International, Justicia y Paz y el Consejo Mundial de Iglesias, entre otras (Rot, 2015).

20 Daniel Cabezas recuerda haber articulado sus tareas políticas en México entre el MPM, donde se sumó al sector de prensa, y el COSOFAM, donde acudió para denunciar la desaparición de su hermano Gustavo, quien fuera militante de Montoneros (Confino, 2014).

$21 \mathrm{Al}$ respecto, recuerda González Gartland: “Cuando Montoneros lanza el MPM más o menos oficialmente, comienzan a tener ciertas actitudes que ya yo no comparto en absoluto porque no eran útiles ni adecuadas para la salida de denuncias en materia de derechos humanos, y porque ya el retaceo de información aumentaba” (Confino, 2016b).

22 Desde 1976, y hasta 1980, la dictadura emprendió acciones de represión extraterritorial, tanto a través del Ejército (en particular su Secretaría de Inteligencia del Estado y el Batallón de Inteligencia 601) como de la Marina (a través del Grupo de Tareas 3.3/2). Al respecto, véase Slatman (2012) y Fernández Barrio (2017).

23 En el documento se plantea el alejamiento de Garzón Maceda, Martín Federico y la renuncia (luego rectificada) de Eduardo Duhalde (CADHU, 1978a).

24 Esta dispersión organizada, presumiblemente, también dependía de las redes políticas que pudieran construirse en los distintos lugares de acogida.

25 Tres meses después del plenario, en abril, la CADHU dirigió un documento al Buró de Información Europeo. Allí se definía como "una organización humanitaria argentina (...) fundada con la finalidad esencial de defender los derechos humanos violados en Argentina por la Junta Militar que actualmente gobierna ese país". Con respecto a sus tendencias internas, planteaba: "La CADHU no tiene objetivos político partidarios y está integrada por hombres y mujeres de todas las tendencias, confesiones e ideologías” (CADHU, 1978b). 
26 Esta mirada del régimen militar sobre la CADHU puede verse, por ejemplo, en DIPPBA (1977 p. 98 y ss). La misma caracterización se desprende de un informe de inteligencia realizado en el marco de los preparativos de la visita de la CIDH y que fue recientemente desclasificado por el gobierno de Estados Unidos (Desclasificados EEUU, 1979).

27 Horacio Maggio fue secuestrado el 15 de febrero de 1977 y llevado a la ESMA de donde consiguió fugarse el 17 de marzo de 1978. Volvió a insertarse en Montoneros y denunció su estadía en el CCD de la Armada y envió cartas a numerosos organismos nacionales e internacionales de derechos humanos. El 4 de octubre de 1978 fue asesinado por el Ejército. Jaime Dri, por su parte, fue secuestrado en Uruguay, el 15 de diciembre de 1977. Había sido diputado nacional por el FREJULI durante la presidencia de Cámpora. Llevado a la ESMA - aunque con un paso previo por la Quinta de Funes, CCD a cargo del Segundo Cuerpo de Ejército en Santa Fe- logró fugarse el 19 de julio de 1978 por la frontera con Paraguay, a donde lo habían trasladado los militares para capturar otros montoneros en la frontera.

28 Un ejemplo de esto lo constituye, por ejemplo, el inicio del testimonio de Dri: "El presente testimonio que voy a brindarles pone en evidencia de forma incontestable ese conjunto de prácticas represivas que hemos denunciado muchas veces como terrorismo de Estado (MPM,1978c).

29 Esta participación no dependió necesariamente de la Conducción, que consideraba a la denuncia por los derechos humanos tan solo como "un medio para parar el enfrentamiento" (Confino, 2016c). No obstante, las redes denuncialistas de Montoneros continuaron funcionando, incluso luego de iniciada la Contraofensiva (Confino, 2018).

30 Agradecemos a Marina Franco habernos hecho conocer este documento.

31 Daniel Cabezas recuerda un ejemplo de estas tensiones: "Cuando desapareció mi vieja, allá [México] estaba Rodolfo Puiggrós con quien yo tenía una buena relación por distintos motivos (...) Lo voy a ver y el "viejo" la mejor onda digamos para ayudarme y comprender todo, fenómeno. Cuando estoy en su casa, viene Fernando Vaca Narvaja con su uniforme, venía de Managua, había entrado al búnker de Somoza, estaba agrandado, él y su mujer. Entonces le digo 'Fernando, yo soy el hijo de Thelma quería saber qué podemos hacer porque creo que mi mamá está viva' y él se da vuelta en una situación medio 'milica' y me dice 'nosotros no hacemos derechos humanos, hacemos política' y se da media vuelta y se va (Confino, 2014).

$32 \mathrm{Al}$ respecto, recuerda Gartland: "Con el tiempo [los montoneros] fueron retaceando la información. ¿Por qué? Porque estaban preparando la Contraofensiva y, al preparar la Contraofensiva, tenían que no denunciar situaciones que le hubieran permitido a los servicios, que ya conocían mucho de la estructura y forma de actuar de los Montoneros, descubrir células dormidas, por ejemplo (Confino, 2016b).

33 El balance de la Contraofensiva de 1979 fue asentado en el último boletín interno que editó Montoneros, el número 13, de febrero de 1980.

34 El documento fue firmado, entre otros, por Miguel Bonasso, Jaime Dri, Pablo Ramos, Daniel Vaca Narvaja y Gerardo Bavio, que luego conformarían "Montoneros 17 de octubre".

35 A ese país se dirigieron, procedentes de Venezuela, Graciela Daleo y Andrés Castillo. También lo hizo Alicia Milia, quien inicialmente había llegado a suelo francés (González Tizón, 2019a y 2019b).

36 Según el recuerdo de los protagonistas, de esas reuniones participaron en distintos momentos y con diversos grados de asiduidad Alicia Milia, Sara Solarz, Ana María Martí, Lila Pastoriza, Pilar Calveiro, Alberto Girondo, Martín Gras, Norma Burgos, Graciela Daleo, Andrés Castillo y Nilda Orazi, aunque es posible que haya habido algún otro participante. La decisión de que el testimonio fuera firmado y presentado solo por Milia, Martí y Solarz se debió a diversos motivos que llevaron al resto de los sobrevivientes a no incluir su nombre: fundamentalmente, estas razones fueron el temor a represalias sobre los familiares - particularmente, los hijos e hijas- que permanecían en la Argentina y los deseos de reincorporarse a la militancia en Montoneros -así sucedió con Graciela Daleo y Andrés Castillo-. El caso de Orazi, resulta ilustrativo del lugar particular que ocupaba la CADHU en el imaginario de los protagonistas: su decisión de no participar del "testimonio de París", tomada último momento, se debió en parte a la posible asociación del organismo con Montoneros. En su lugar, prefirió presentar su relato con el auspicio del COSOFAM en una conferencia de prensa que se realizó en la capital francesa en septiembre de 1979, en paralelo a la visit37a de la CIDH a la Argentina.

37 En su libro sobre el PROA, Rot afirma que, luego de establecerse en Madrid, Massaferro se convirtió en "una suerte de agente diplomático, viajando constantemente a Bélgica, Suecia, Italia, Holanda, Suiza, Inglaterra y Francia” (Rot, 2015, p. 274). Para una reconstrucción de su trayectoria de vida, véase Giussani (2005).

38 Sobre esta cuestión, Milia recuerda que "Había un tipo que creo que era holandés, que Lili era muy amiga de él, este tipo consiguió un montón de cosas, que se llamaba Van Boven. Él tenía algo que ver con el tema de la ONU en Suiza" (González Tizón, 2019b).

39 Instaladas en Valencia, Ana María Martí y Sara Solarz serían vigiladas y hostigadas de manera recurrente por el exprefecto Héctor Febres, integrante del GT de la ESMA a cargo de las secuestradas embarazadas y, como tal, engranaje fundamental del dispositivo de apropiación de niños y niñas nacidos en cautiverio diseñado en el CCD de la Armada. Para más información al respecto ver, Dandán (2017).

40 Sobre el proceso de redacción del testimonio, Daleo recuerda que "el texto escrito, lo que se presenta ese 12 de octubre, lo terminamos de armar a máquina, que era mi rol de dactilógrafa, en el hotel este de la calle Vargas, de Madrid, juntando 
lo que había ido anotando, recordando, y algunos que no estuvieron en esa reunión, pero que habían estado previamente en las discusiones, también habían aportado sus memorias" (González Tizón, 2019a).

41 El testimonio original, con una versión en español y otra en francés, incluía ya en su carátula el sello de la CADHU con la descripción de las siglas del organismo en esos dos idiomas y en inglés (agradecemos a Alicia Milia la gentileza de habernos facilitado su ejemplar del testimonio para poder utilizarlo en este trabajo).

42 La conferencia de prensa tuvo lugar el 20 de septiembre de 1978. Del lado del PSF, participaron del evento Lionel Jospin y François Mitterrand, quienes poco tiempo después se desempeñarían como primer ministro y presidente de Francia, respectivamente. Por el lado de Montoneros, además de Dri participaron Flora Castro de Habegger, esposa de Norberto Habegger (dirigente montonero desaparecido en Brasil en agosto de 1978), y Fernando Vaca Narvaja, miembro de la Conducción.

43 El 14 de octubre de 1979, a raíz de la denuncia de las tres sobrevivientes de la ESMA, el diario francés Liberátion denunció en tapa la presencia de un miembro del grupo de tareas en el Centro Piloto bajo el título "Un torturador argentino designado en París". También dio cuenta del testimonio el periódico español El País, que en un artículo del 13 de octubre de 1979 señalaba a sus autoras como "Las tres mujeres supervivientes de los desaparecidos de la Argentina”. Dos meses más tarde, Presencia Argentina, publicación del Centro Argentino de Madrid, reprodujo el relato en un artículo titulado “Testimonio de la Escuela de Mecánica” (Presencia Argentina, 1979).

44 Sintetizada en la polémica sobre el significado del "traslado", la afirmación acerca del asesinato de la mayoría de los desaparecidos generó amargos intercambios entre diversos representantes del activismo antidictatorial en Argentina y el exilio, y contribuyó significativamente a que algunos de ellos estigmatizaran a los sobrevivientes de los CCD como "traidores" o cómplices de la dictadura (Franco, 2008; Jensen, 2010; González Tizón, 2021).

45 Las tres mujeres coincidían en atribuir su secuestro a su actividad política en la organización armada peronista: Ana María Martí sostenía que "fui secuestrada por ser militante del Peronismo montonero y luchar por la liberación de mi patria”; Alicia Milia afirmaba que "fui secuestrada por ser Peronista montonera” y, finalmente, Sara Solarz declaraba que "fui secuestrada el día 14 de mayo de 1977 por ser miembro del Movimiento Peronista Montonero" (CADHU, 1979, pp. 9, 13 y 15). Esta explicitación de la militancia, con distintos grados de asunción de la práctica armada, sería un componente distintivo de la serie de testimonios publicada por la CADHU, inaugurada con el de París, entre 1979 y 1983 (González Tizón, 2016). 